\title{
Gaseous exchanges of corn and weeds under competition and water regimes
}

\author{
Claudia D. M. Freitas ${ }^{1}$, Juliana de P. Pamplona ${ }^{1}$, Hamurábi A. Lins ${ }^{1}$, Matheus de F. Souza ${ }^{1}$, \\ Jeferson L. D. Dombroski ${ }^{1} \&$ Daniel V. Silva ${ }^{1}$
}

${ }^{1}$ Universidade Federal Rural do Semi-Árido/Departamento de Ciências Agronômicas e Florestais, Mossoró, RN, Brasil. E-mail: claudiamelof@hotmail.com - ORCID: 0000-0001-5243-5071; juliana_paiva_pamp@hotmail.com - ORCID: 0000-0002-7185-1553; hamurabi_a_@hotmail.com (Corresponding author) - ORCID: 0000-0002-4548-9108; matheus_mafs10@hotmail.com - ORCID: 0000-0002-5424-6028; jeferson@ufersa.edu.br - ORCID: 0000-0002-7888-1456; daniel.valadao@ufersa.edu.br - ORCID: 0000-0003-0644-2849

\begin{abstract}
Water deficits can alter vital physiological functions and negatively affect plant growth. These effects can be intensified by weeds competing for water available to crops. The objective of this study was to evaluate the effects of competition and temporary soil water deficit on the transpiration (E), stomatal conductance (gs) and photosynthetic rate (A) of corn, Urochloa decumbens, and Bidens pilosa L. The experimental design was in randomized blocks with eight repetitions. The treatments were arranged in a $5 \times 2$ factorial scheme, with the first factor corresponding to the species: corn $+U$. decumbens, corn $+B$. pilosa, and corn, $U$. decumbens, and B. pilosa without competition. The second factor was two water regimes: daily irrigation and water restriction, which corresponded to the suspension of irrigation from the beginning of the V3 stage of corn until the time when their stomata were completely closed. The species B. pilosa and $U$. decumbens worsened the negative effects on $\mathrm{E}$, gs, and A of corn at different intensities under water restriction. The $U$. decumbens was more aggressive in relation to B. pilosa while coexisting with corn in both water regimes. The competition with corn affected the $\mathrm{E}$ and gs of $U$. decumbens in the two water regimes, but the A was altered under water deficit. On the other hand, the physiological components of $B$. pilosa were not affected by its coexistence with corn in the two water regimes.
\end{abstract}

Key words: Zea mays L., Urochloa decumbens, Bidens pilosa L.

\section{Trocas gasosas do milho e de plantas daninhas sob competição e regimes hídricos}

RESUMO: O déficit hídrico pode alterar funções fisiológicas vitais e afetar negativamente o crescimento das plantas. Esses efeitos podem ser intensificados pelas plantas daninhas que competem pela água disponível para as culturas. O objetivo foi avaliar os efeitos da competição e do déficit hídrico temporário do solo sobre a transpiração (E), condutância estomática (gs) e taxa fotossintética (A) do milho, da Urochloa decumbens e da Bidens pilosa L. O delineamento experimental foi em blocos casualizados, com oito repetições. Os tratamentos foram arranjados em esquema fatorial $5 \times 2$, com o primeiro fator correspondente às espécies milho + U. decumbens, milho + B. pilosa, e milho, U. decumbens e B. pilosa sem competição, e o segundo fator dois regimes hídricos, irrigação diária e restrição hídrica, que correspondeu à suspensão da irrigação desde o início do estágio V3 do milho até o momento em que seus estômatos ficaram totalmente fechados. As espécies $B$. pilosa e $U$. decumbens agravaram em diferentes intensidades os efeitos negativos sobre E, gs e A do milho em condição de restrição hídrica. A $U$. decumbens foi mais agressiva em relação a $B$. pilosa em competição com o milho, em ambos regimes hídricos. A competição com o milho afetou a E e gs da $U$. decumbens nos dois regimes hídricos, mas a A foi alterada sob déficit hídrico. Por outro lado, os componentes fisiológicos de B. pilosa não foram afetadas pela competição com o milho, nos dois regimes hídricos.

Palavras-chave: Zea mays L., Urochloa decumbens, Bidens pilosa L. 


\section{INTRODUCTION}

Corn (Zea mays L.) is one of the most produced cereals in the world. The crop is planted in tropical, subtropical, and semi-arid regions (Cutti et al., 2016). However, stressful conditions can hamper productive stability in each region (Mickelbart et al., 2015).

Abiotic stresses alter growth and development, which can reduce the productivity and quality of the harvested product (Mickelbart et al., 2015). Among the abiotic factors, the water deficit in the soil is one of the most relevant (Uzildaya et al., 2012).

Under conditions of water restriction, plants tend to decrease stomatal conductance as a strategy to prevent water loss to the atmosphere. However, the complete closure of stomata prevents the entry of $\mathrm{CO}_{2}$ and, consequently, the photosynthetic rate is reduced as the severity of water stress increases (Lisar et al., 2012).

Several factors can increase the severity of water stress. In addition to those environmental factors directly involved with the decrease in water availability in the soil, other factors may intensify the negative effect of the water deficit, such as the presence of weeds (Dass et al., 2017).

Weeds can present different functioning strategies depending on water availability, some of which are more sensitive to this stress and others more tolerant (Lima et al., 2016). These different forms of adaptation to stress can give greater or lesser competitive capacity compared to crops.

Thus, the objective of this study was to evaluate the effect of competition on transpiration (E), stomatal conductance (gs), and photosynthetic rate (A) of corn (Zea mays L.), brachiaria (Urochloa decumbens) and beggarticks (Bidens pilosa L.) under conditions of temporary soil water deficit.

\section{Material ANd Methods}

The experiment was conducted from May to June 2017 in a greenhouse. The experimental unit corresponded to a plastic vessel with a volumetric capacity of $8.5 \mathrm{dm}^{3}$ filled with Inceptisol collected from the $0-20 \mathrm{~cm}$ layer. The physical and chemical characteristics of the soil were as follows. The $\mathrm{pH}$ (water) was 7.2, EC was $0.14 \mathrm{dS} \mathrm{m}^{-1}$, and $\mathrm{OM}$ was $8.10 \mathrm{~g} \mathrm{~kg}^{-1}$. The $\mathrm{P}, \mathrm{K}$, and Na were $2.2,434.6$, and $49.3 \mathrm{mg} \mathrm{dm}^{-3}$, respectively. The Ca, Mg, Al, H + Al, and effective CTC were 11.30, 2.10, 0, 0, and $14.73 \mathrm{cmol} \mathrm{dm}^{-3}$, respectively. The sand, silt, and clay were $0.57 ; 0.10$; and $0.33 \mathrm{~kg} \mathrm{~kg}^{-1}$, respectively, indicating an obvious sandy clay texture. Fertilization was carried out by applying $45.50 \mathrm{mg} \mathrm{dm}^{-3}$ of monoammonium phosphate at planting. The cover fertilization was done 15 days after planting with 33.3 and $16.67 \mathrm{mg} \mathrm{dm}^{-3}$ of urea and potassium chloride, respectively.

The experimental design was in randomized blocks, whose treatments were arranged in a $5 \times 2$ factorial scheme with four replications. The first factor corresponded to the species: Z. mays + U. decumbens, Z. mays + B. pilosa, and Z. mays, U. decumbens, and $B$. pilosa without competition. The second factor was the water regime, either daily irrigation or water restriction, which corresponded to the suspension of irrigation from the beginning of the V3 stage of corn until the time when their stomata were completely closed. The hybrid corn cultivar 'AG-1051', Urochloa decumbens (braquiária) and Bidens pilosa (beggarticks) were submitted to preliminary germination and emergence tests to establish the sowing period of each species, so that the emergence was simultaneous. Corn and weed seeds were sown in the center and on the edge of each experimental unit, respectively. Thinning was carried out five days after emergence, with only one plant of each species remaining in the pot.

Irrigations were carried out daily in all experimental units, keeping the humidity close to the field capacity (70-80\%). The soil moisture values of the field capacity (FC) and at the permanent wilt point (PWP) were 0.345 and $0.113 \mathrm{~cm}^{3} \mathrm{~cm}^{-3}$, respectively, resulting in a total storage $(\mathrm{AD})$ of $0.232 \mathrm{~cm}^{3} \mathrm{~cm}^{-3}$. The volume of water applied to each pot was obtained by the difference between the weight of the pot in its field capacity and the weight at the end of each day, according to the methodology proposed by Sousa et al. (2015).

The change in water regimes started when the corn plants had their third leaf expanded (stage V3), a stage in which weeds can reduce corn productivity by 10 to $15 \%$ (Gantoli et al., 2013). In treatments with water restriction, the water deficit was established only once with the suspension of irrigation and maintained until the time when the stomata of the corn plants were completely closed, with the $\mathrm{CO}_{2}$ assimilation rates reaching values close to zero.

The period required for the $\mathrm{CO}_{2}$ assimilation rate to reach zero was 5 days. From this moment on, irrigation was restored, keeping the humidity close to the field capacity again. For this, all the water-restricted treatment vessels were weighed, applying the volume of water referring to the difference between the weight of the vessels after the stress period and the weight of the vessels in the field capacity.

On average, the mean total water depth applied was equivalent to $154.2 \mathrm{~mm}$ in treatments irrigated daily, and $93.8 \mathrm{~mm}$ in the treatments subjected to temporary water deficit. The climatic conditions in the greenhouse were a maximum temperature of $35 \pm 2{ }^{\circ} \mathrm{C}$, an average temperature of $28 \pm 2{ }^{\circ} \mathrm{C}$, a minimum temperature of $20 \pm 2{ }^{\circ} \mathrm{C}$, and relative humidity of $65 \pm 5 \%$.

The measurement of gas exchange was performed daily from the suspension of irrigation until the time when the photosynthetic rate of plants subjected to temporary water deficit was similar to plants irrigated daily. The net photosynthetic rate $\left(\mathrm{A} ; \mu \mathrm{mol} \mathrm{CO}_{2} \mathrm{~m}^{-2}\right)$, stomatal conductance (gs; $\left.\mu \mathrm{mol} \mathrm{H}_{2} \mathrm{O} \mathrm{m}^{-2} \mathrm{~s}^{-1}\right)$ and transpiration $\left(\mathrm{E} ; \mathrm{mmol} \mathrm{H}_{2} \mathrm{O} \mathrm{m}^{-2} \mathrm{~s}^{-1}\right.$ ) were evaluated with the aid of an infrared gas analyzer (IRGA, portable model LI-6400, LI-COR Biosciences') (Lima et al., 2016), readings were taken between 8 and 10 a.m. The $\mathrm{CO}_{2}$ concentration was fixed at $400 \mu \mathrm{mol} \mathrm{mol}^{-1}$ and the light intensity at $1500 \mu \mathrm{mol}$ of photons $\mathrm{m}^{-2} \mathrm{~s}^{-1}$. The evaluations were made on young leaves that newly expanded and undamaged.

The data were submitted to analysis of variance by test $F$ ( $\mathrm{p} \leq 0.05)$. When significant, the means were compared using the Tukey test at $\mathrm{p} \leq 0.05$. The statistical software used was SISVAR ${ }^{\circ}$ 5.6. The graphics were made using the Sigmaplot 12.0 software.

\section{Results AND Discussion}

The water regime and species factors showed significant interaction. In corn plants grown alone, the temporary water 
deficit reduced transpiration (E) from the third to the fifth day of water restriction. After the resumption of irrigation, the transpiration of the plants increased until reaching values similar to those cultivated under daily irrigation (Figure 1A).

The smallest amount of water available due to evapotranspiration can alter the physiological behavior of plants in several ways. Corn plants probably reduced their transpiration to maintain their leaf tissue turgor due to reduced water availability (Rodrigues et al., 2014).

The presence of $U$. decumbens next to corn, under irrigated conditions reduced the transpiration of the crop (from the third to the eighth day) in relation to the isolated cultivation (Figures $1 \mathrm{~A}$ and $\mathrm{B})$. With water restriction, the reduction in transpiration of corn plants was observed throughout the evaluated period (Figure 1B). Unlike B. pilosa, U. decumbens is a monocot and its root explores the same region as corn plants (Rodrigues et al., 2014), reducing the water available for the crop. The competition severity increased in the condition of water restriction, and in response to this condition, the corn plants reduced their $\mathrm{E}$ to values lower than the irrigated treatment.

Unlike $U$. decumbens, the presence of B. pilosa did not affect plant transpiration compared to isolated corn cultivation under irrigated conditions (Figures $1 \mathrm{~A}$ and $\mathrm{C}$ ). In the water deficit, the reduction in transpiration occurred until the fifth day after the water restriction (Figure 1C). The corn and B. pilosa plants may have explored different regions of the substrate due to the root morphology of these species. B. pilosa has a pivoting root, and it is capable of reaching greater depths in the soil (Yan et al., 2016). Conversely, the roots of the corn are concentrated in the superficial layers (fasciculate); therefore, B. pilos $a$ plants absorb water in deeper regions of the soil, do not restrict the amount of water available to corn plants. This fact can explain the similar E between treatments in competition and isolated both in daily irrigation and in water restriction.
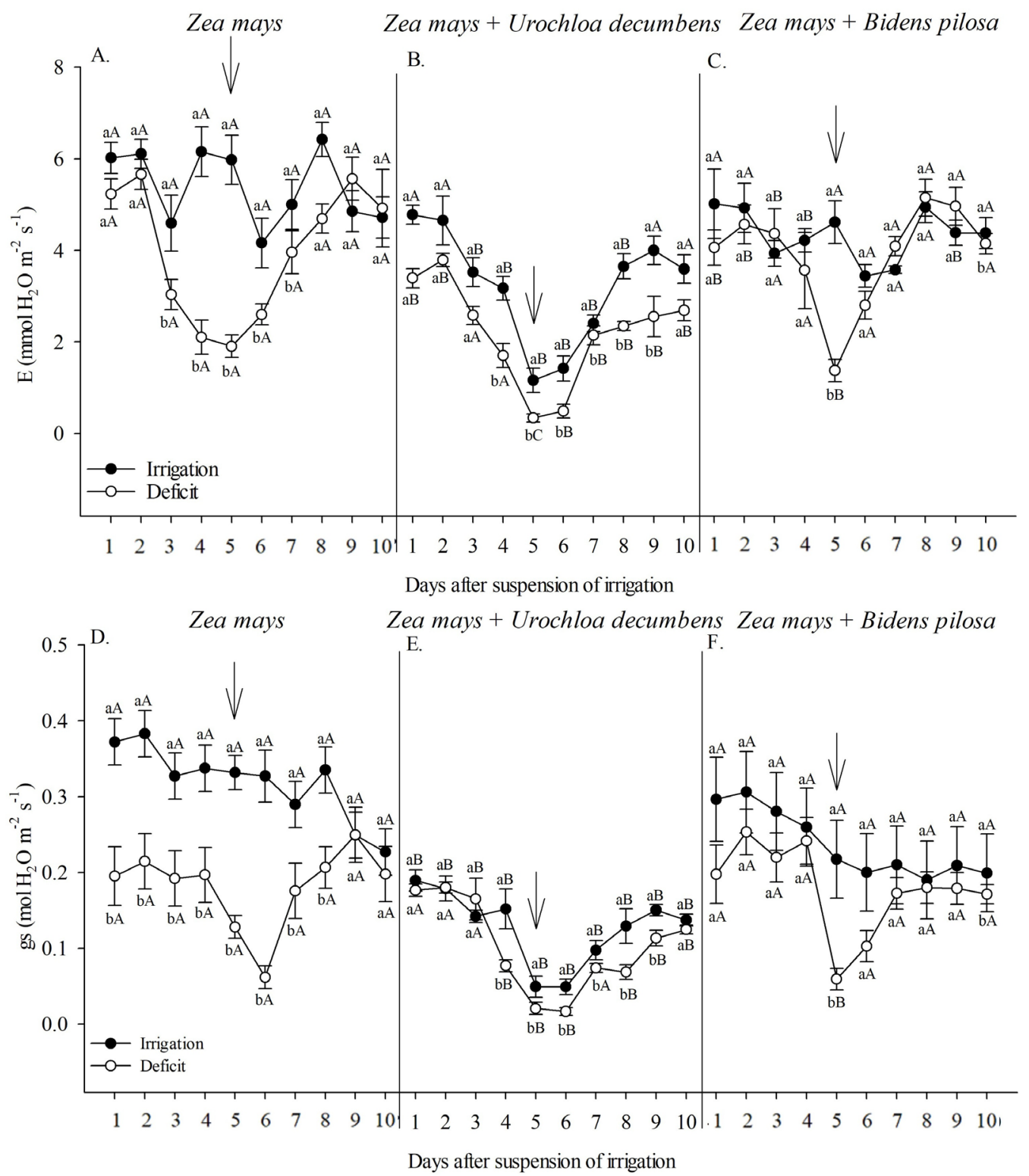

The uppercase letters compare the competition between plants and the lowercase letters compare the water regimes within each species at $\mathrm{p} \leq 0.05$ by the Tukey test. Bars indicate the standard error of the mean. The arrows indicate the timing of the return of irrigation

Figure 1. Transpiration rate (E) and stomatal conductance (gs) of corn plants in monoculture (A and D) and in competition with $U$. decumbens (B and $\mathrm{E}$ ) and with B. pilosa ( $\mathrm{C}$ and $\mathrm{F}$ ), submitted to two water regimes, which were daily irrigation and water deficit 
The stomatal conductance (gs) of corn plants grown alone was lower in the condition of water restriction from the third to the eighth day (Figure 1D). The gs measured in the leaves can be changed due to two factors: the change in stomatal opening and the vapor pressure deficit (VPD) between the interior of the leaf and the atmosphere (Ryan et al., 2016).

Despite the lower gs on the first and second day after the end of irrigation indicating reductions in stomatal openings, the transpiration of corn plants was not affected. In the initial periods, the corn leaves were still hydrated, and probably the humidity of the sub-stomatal chamber was close to $100 \%$. The high humidity inside the leaves may have favored the loss of water vapor due to the higher VPD generated, even in conditions of less stomatal opening (Ryan et al., 2016). However, as the leaf cells lose water, the moisture inside the leaf and the VPD are reduced, resulting in the least transpiration observed from the third day on under water restriction.

The presence of $B$. pilosa reduced corn gs only on the fifth day after the end of irrigation (Figure 1F). On the other hand, competition with $U$. decumbens reduced the gs of the crop in all days of evaluation in the irrigated regime (Figure 1E). Furthermore, in the presence of $U$. decumbens and after the fourth day of water restriction, the gs of the corn plants were even lower compared to all other treatments (Figure 1E).

Corn and $U$. decumbens have a $\mathrm{C} 4$ carbon fixation mechanism, which allows these species to grow and accumulate dry matter even under conditions with less water availability. However, if the amount of water available from the soil was rapidly reduced, it can affect the physiological mechanism of the plants, as observed in the pots with the presence of these two species. The response of corn to the condition of low soil moisture when in coexistence with $U$. decumbens in both water regimes was to reduce the loss of water to the atmosphere through stomatal closure, explaining the lower gs and E measures. The ability of corn plants to close their stomata is related to the general signal due to water deficit in the soil. Under these conditions, the plants increase the synthesis of abscisic acid (ABA) in their roots, and export this hormone to the leaves, signaling to the cells the condition of water restriction (Lisar et al., 2012). Once the cells receive the signal, the guard cells lose turgor, promoting the stomatal closure necessary to reduce $\mathrm{E}$.

The photosynthetic rate (A) observed in treatments with isolated corn was lower under the water restriction (Figure 2A).

Except for the reduction of $A$ on the sixth day after the suspension of irrigation, the species $B$. pilosa did not affect the $A$ of corn plants under the daily irrigation regime on the other evaluated days (Figures $2 \mathrm{~A}$ and $\mathrm{C}$ ). The presence of B. pilosa did not affect the A of corn under water deficiency, compared to isolated corn, except on the ninth day (Figures 2A and C).

Corn plants when in competition with $B$. pilosa showed a reduction in gs on the fifth day. However, A did not change in this treatment. This fact can be explained due to the $\mathrm{CO}_{2}$ concentration mechanism inside the cells of the vascular bundle sheath (Geissler et al., 2015). Despite the lower influx of atmospheric $\mathrm{CO}_{2}$ resulting from the partial closure of stomata, corn plants were able to maintain constant photosynthesis due to PEP-carboxylase, an enzyme that fixes atmospheric carbon more quickly, even at very low concentrations of carbon gas.

The presence of $U$. decumbens in the pots reduced the $\mathrm{A}$ of the corn plants from the fifth to the ninth day under daily irrigation (Figures 2A and B). The lowest value for A was observed in the treatment with water deficit and competition with $U$. decumbens (Figure $2 \mathrm{~B}$ ). The photosynthetic rate (A) equal to the corn monoculture verified in the competition with $B$. pilosa was not observed when the corn competed with $U$. decumbens in both water regimes. In this treatment, the gs reached values close to zero, indicating the total closure of the stomata. Despite the $\mathrm{CO}_{2}$ concentration mechanism, a minimum amount is necessary for corn plants to maintain their positive net photosynthesis (Geissler et al., 2015). Thus, in treatments in competition with

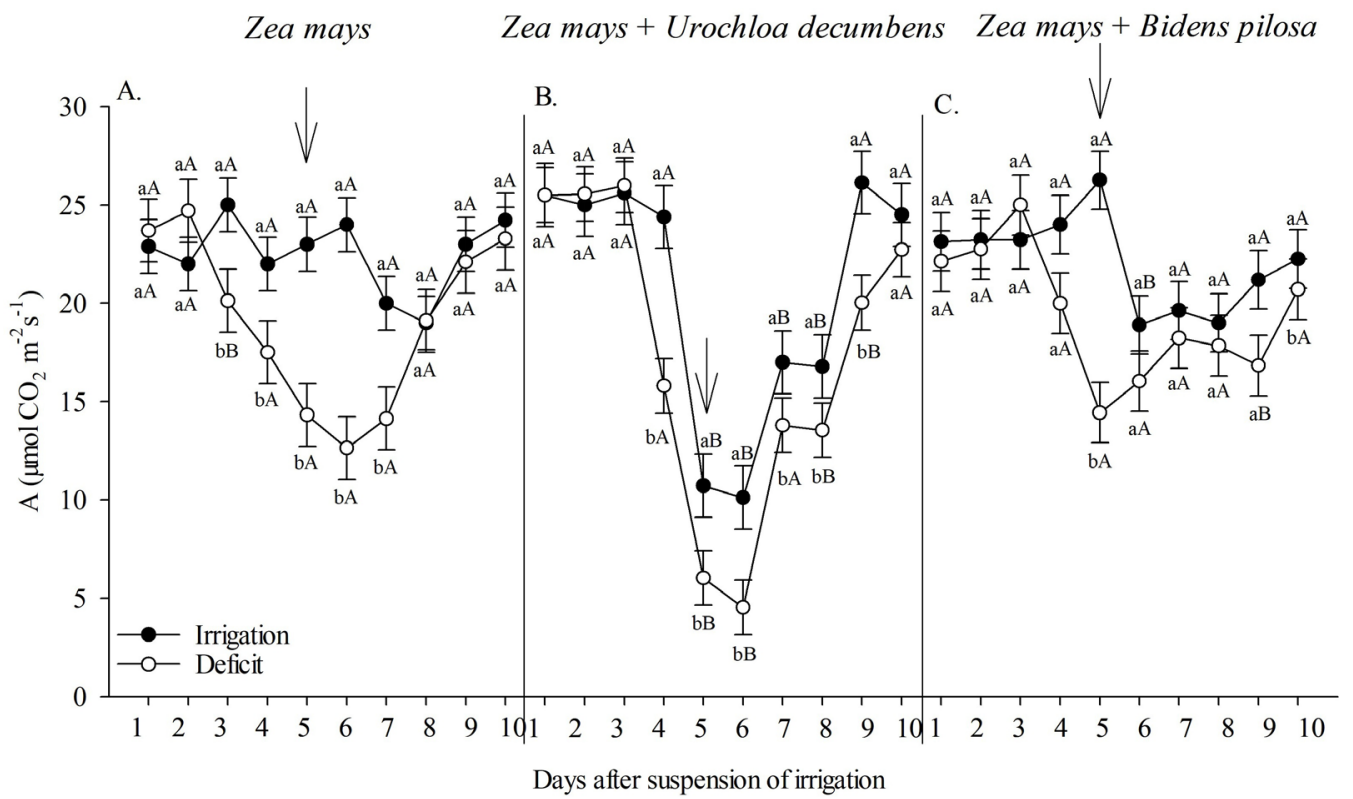

The uppercase letters compare the competition between plants and the lowercase letters compare the water regimes within each species at $\mathrm{p} \leq 0.05$ by the Tukey test. Bars indicate the standard error of the mean. The arrows indicate the timing of the return of irrigation

Figure 2. Photosynthetic rate (A) of corn plants in monoculture (A) and in competition with U. decumbens (B) and B. pilosa (C), submitted to two water regimes, which were daily irrigation and water deficit 
$U$. decumbens, the $\mathrm{CO}_{2}$ concentration in the leaf tissues may have reached values below the compensation point, reducing the A of these plants.

The corn plants recovered A after the resumption of irrigation (Figure 2A). However, A recovery was slower in corn plants grown with $U$. decumbens, irrigated or not (Figure $2 \mathrm{~B}$ ). In conditions of water deficit, the presence of $U$. decumbens delayed recovery of A by 1 day (Figure $2 \mathrm{~B}$ ). The resumption of the photosynthetic rate in corn plants followed the same behavior as gs, proving the direct relationship between $\mathrm{CO}_{2}$ absorption and photosynthesis (Miner et al., 2017). Other mechanisms do not have the same resilience when subjected to water stress. For example, the water deficit strengthens the mechanical properties of the wall, affecting leaf expansion when this tissue is rehydrated (Tenhaken, 2015).

In isolated crops, the $\mathrm{E}$ and gs of $U$. decumbens plants were lower in the water restricted regime (Figures $3 \mathrm{~A}$ and $\mathrm{C}$ ). When coexisting with corn plants, U. decumbens showed lower $\mathrm{E}$ and gs, even in irrigated systems (Figures $3 \mathrm{~B}$ and $\mathrm{D})$.
The lowest values of $\mathrm{E}$ and gs were obtained when $U$. decumbens was harvested under hydraulic restriction and in competition with corn (Figures $3 \mathrm{~B}$ and D).

As in corn plants, the water deficit in the soil generated a stimulus that allowed $U$. decumbens to reduce water loss via stomata. This mechanism allows plants to withstand situations of water deficit in the soil (Sharma et al., 2015). Although stomatal closure reduces the influx of atmospheric $\mathrm{CO}_{2}$ in the leaf mesophile, the lower gs observed in the leaves of $U$. decumbens reduced transpiration and water loss, maintaining the turgescence of plant tissues. After the resumption of irrigation, both in isolated crops and in competition, the plants of $U$. decumbens did not restore their gs (Figure 3).

Plants can adjust their physiological system when subjected to different stresses (Tenhaken, 2015; Miner et al., 2017). In corn plants, the resumption of irrigation increased the values of $\mathrm{E}$ and gs; however, $U$. decumbens did not show the same behavior regarding these variables. Unlike corn, the temporary water deficit in the soil prolonged the physiological mechanisms of $U$. decumbens. Even after the resumption of
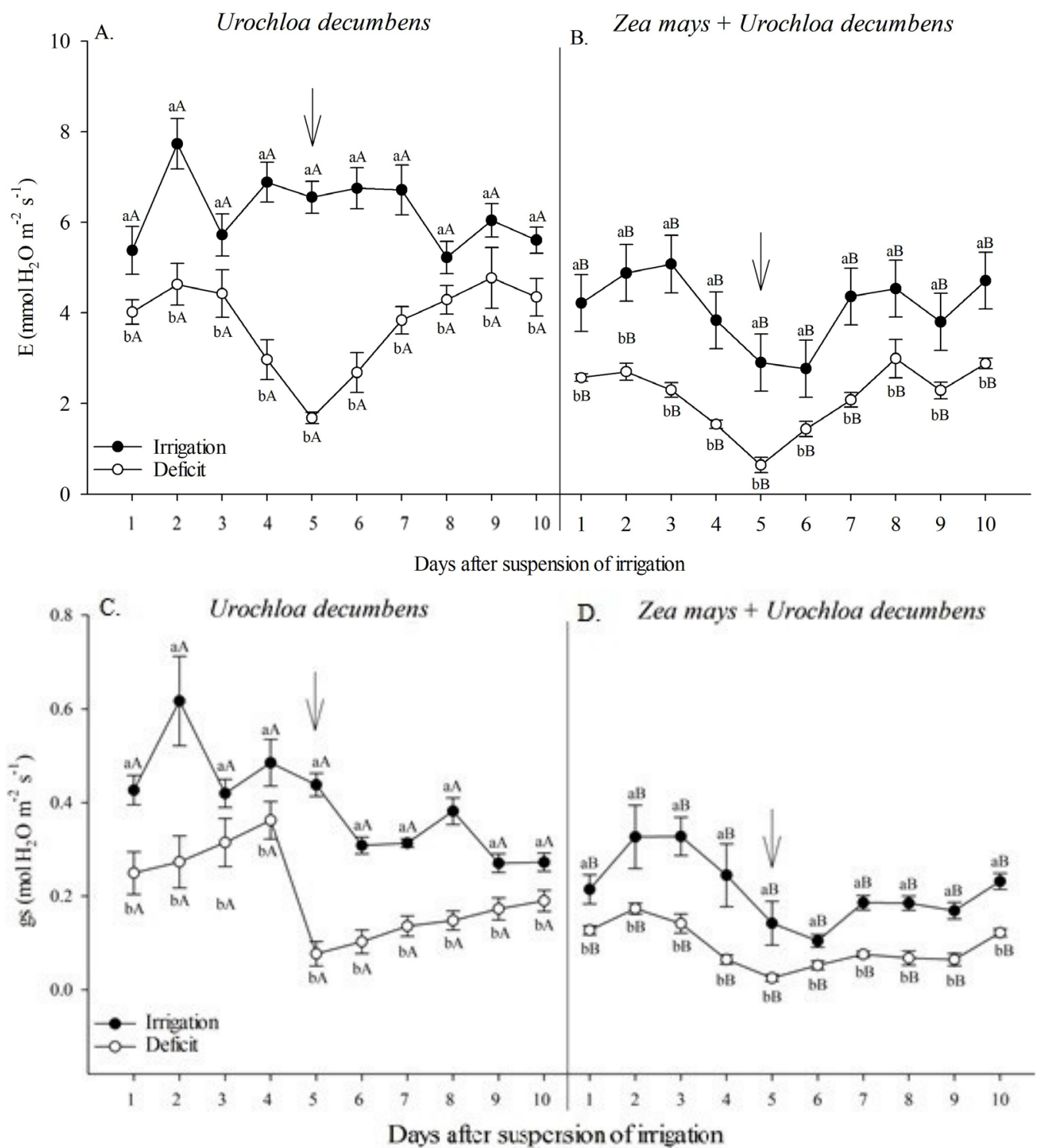

The upercase letters compare the competition between plants and the lowercase letters compare the water regimes within each species at $\mathrm{p} \leq 0.05$ by the Tukey test. Bars indicate the standard error of the mean. The arrows indicate the timing of the return of irrigation

Figure 3. Transpiration rate (E) and stomatal conductance (gs) of U. decumbens plants in monoculture (A and C) and in competition with corn (B and D), submitted to two water regimes: daily irrigation and water deficit 
irrigation, $U$. decumbens plants in competition with corn still maintained low values of $\mathrm{E}$ and gs. This behavior shows that $U$. decumbens did not respond to the greater availability of water (Moshelion et al., 2015).

The difference in behavior between corn and $U$. decumbens can be associated with the life cycle of these species. $U$. decumbens is a perennial species, so ensuring that a new stressful condition does not occur is a mechanism to ensure its survival. Conversely, corn is a species of annual growth, and it needs to invest to generate decent income as an alternative to perpetuating the species (Loon, 2016). In other species, it is possible to observe that abiotic stresses such as water deficit accelerate flowering for seed production (Loon, 2016).

The photosynthetic rate (A) of $U$. decumbens did not change when in competition with corn under an irrigated regime, except on the sixth and seventh day (Figure 4B). In treatments with water restriction, competition with corn reduced the A of $U$. decumbens from the fourth to the sixth day (Figure 4B).

The reduction of gs in conditions of isolated cultivation under water restriction and competition under irrigation did not affect the A of $U$. decumbens. Lower gs values imply less atmospheric $\mathrm{CO}_{2}$ absorption for mesophilic cells, and, consequently, less fixed carbon. However, the carbon concentration mechanism of $U$. decumbens was efficient, allowing the reduction of water loss without affecting carbon fixation. Only the condition of high severity of stress (regime with water restriction and competing with corn) was able to reduce the values of gs to the point of damaging $A$.

The $\mathrm{E}$ and gs of $B$. pilosa plants were higher without competition with corn and with water restriction from the first to the third day after the suspension of irrigation (Figures $5 \mathrm{~A}$ and $\mathrm{C}$ ). After this period, there was no difference between the two water regimes for the values of $\mathrm{E}$ and gs (Figures $5 \mathrm{~A}$ and $\mathrm{C}$ ).
The high $\mathrm{E}$ and gs in the initial periods of treatment without competition with corn may be a strategy of B. pilosa to increase the extraction of water from the soil after the end of irrigation. Among the mechanisms of adaptation to drought, some plants can increase their capacity to absorb water from the soil, either by the greater accumulation of solutes in the roots or by the greater negative pressure formed by the transpiratory process (Fang \& Xiong, 2015).

When recognizing the sign of less water availability, B. pilosa increased the gs in its stomata, resulting in a higher E. Greater water loss due to greater E can reduce the water potential value in the plant, increasing water absorption in the soil (Fang \& Xiong, 2015). However, this behavior was observed only in the initial periods after the end of irrigation. As the amount of water in the soil was reduced, $B$. pilosa kept the gs at levels similar to the treatment without competition and irrigated.

The photosynthetic rate (A) of B. pilosa plants was higher only in the isolated treatment with water restriction (Figure $6 \mathrm{~A}$ ). This greater A was observed only from the first to the third day after the end of the irrigation (Figure 6A).

This behavior was a reflection of the greater gs measured in the plants, which allowed a greater influx of $\mathrm{CO}_{2}$ inside the leaf mesophyll. B. pilosa is a C3 species, and the higher concentration of $\mathrm{CO}_{2}$ in the mesophile increases carbon fixation (reduces photorespiration), allowing the greater accumulation of dry matter (Ehlers et al., 2015).

The greater A of B. pilosa plants in the initial periods of water restriction may result in a greater amount of photoassimilates available for root growth, due to osmotic adjustment and better efficiency of the photosystems and enzymes involved (Luo et al., 2016). Since the roots of this species explore a larger volume of soil, the capacity to absorb the available water is increased, thus increasing the tolerance to water stress. However, in conditions of greater severity of stress (water restriction plus competition) and the absence

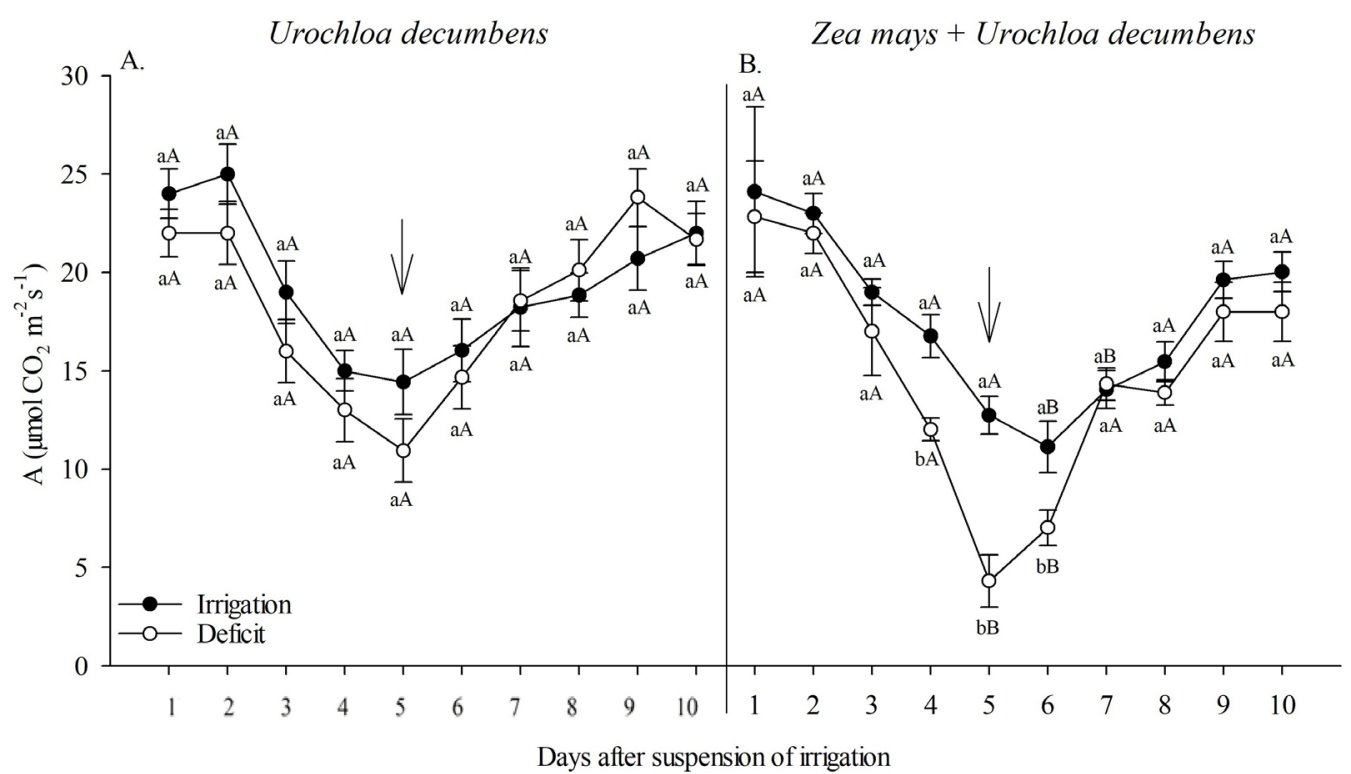

The uppercase letters compare the competition between plants and the lowercase letters compare the water regimes within each species at $\mathrm{p} \leq 0.05$ by the Tukey test. Bars indicate the standard error of the mean. The arrows indicate the timing of the return of irrigation

Figure 4. Photosynthetic rate (A) of $U$. decumbens plants in monoculture (A) and in competition with corn (B), submitted to two water regimes: daily irrigation and water deficit 

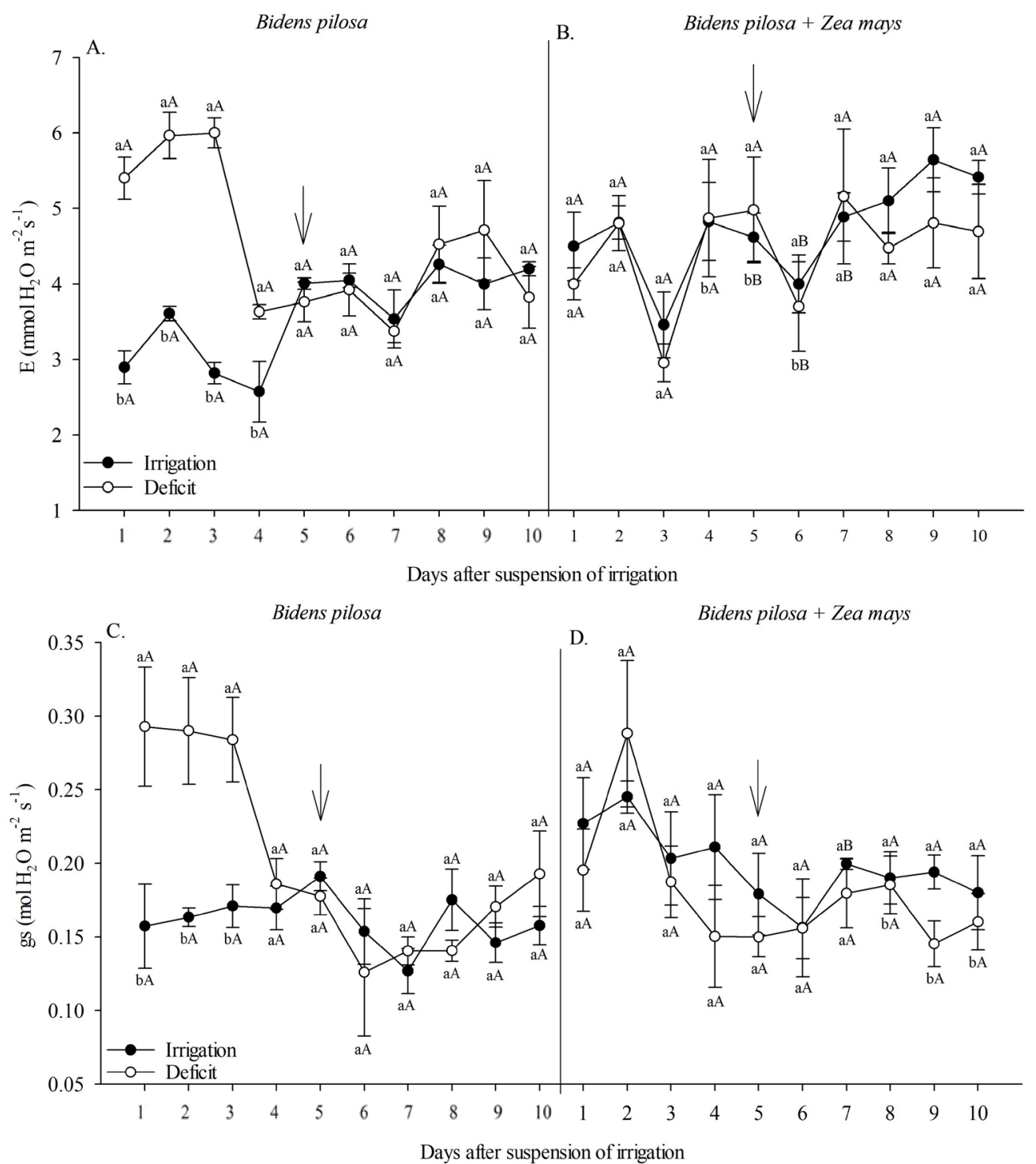

The uppercase letters compare the competition between plants and the lowercase letters compare the water regimes within each species at $\mathrm{p} \leq 0.05$ by the Tukey test. Bars indicate the standard error of the mean. The arrows indicate the timing of the return of irrigation

Figure 5. Transpiration rate (E) and stomatal conductance (gs) of B. pilosa plants in monoculture (A and C) and in competition with corn (B and D), submitted to two water regimes: daily irrigation and water deficit

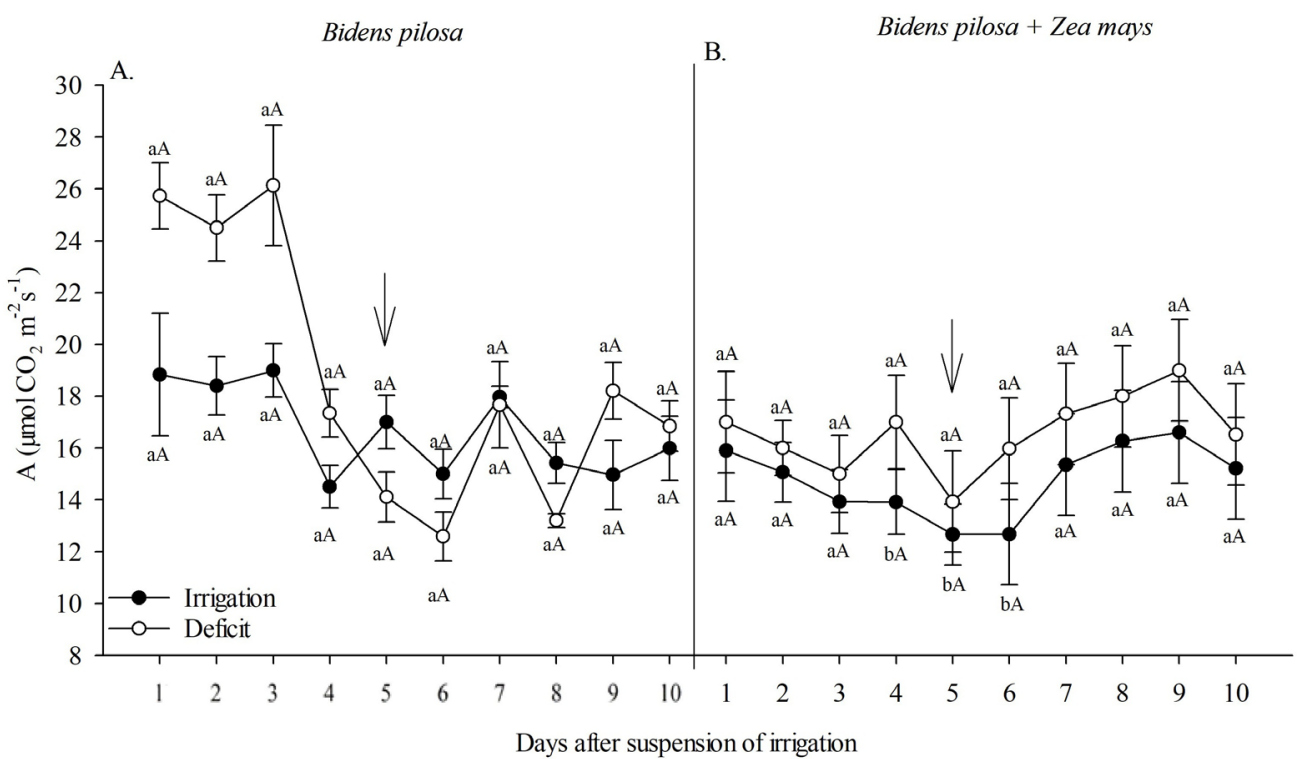

The uppercase letters compare the competition between plants and the lowercase letters compare the water regimes within each species at $\mathrm{p} \leq 0.05$ by the Tukey test. Bars indicate the standard error of the mean. The arrows indicate the timing of the return of irrigation

Figure 6. Photosynthetic rate (A) of B. pilosa plants in monoculture (A) and in competition with corn (B) submitted to two water regimes: daily irrigation and water deficit 
of water stress, the behavior responsible for the increase in $\mathrm{A}$ was not evident.

The negative changes resulting from water restriction were aggravated due to the presence of weeds, and these were greater when corn competed with $U$. decumbens. These grasses have some physiological and morphological similarities, and, therefore, compete for the same resources at a similar intensity, which does not happen between corn and B. pilosa, explaining the lesser competition between these species.

The species $U$. decumbens and B. pilosa behaved differently after the imposition of water restriction and when in competition with corn. The physiological adjustments of each weed allow them to survive underwater deficit conditions. In addition, this difference in behavior was directly linked to the competitive capacity exercised on corn.

\section{Conclusions}

1. The species $B$. pilosa and $U$. decumbens aggravated the negative effects on transpiration (E), stomatal conductance (gs), and the photosynthetic rate (A) of corn under water restriction to different intensities.

2. Urochloa decumbens was more aggressive in relation to B. pilosa in competition with corn, with daily irrigation and with water deficit.

3. The competition with corn affected the E and gs of $U$. decumbens in the two water regimes and the A was changed only when the plants were coexisting under a water deficit. The $\mathrm{E}$, gs and A of B. pilosa plants were not affected by competition with corn, in both water regimes.

\section{ACKNOWLEDGMENTS}

This study was financed in part by the Coordenação de Aperfeiçoamento de Pessoal de Nível Superior - Brasil (CAPES) - Finance Code 001.

\section{Literature Cited}

Cutti, L.; Lamego, F. P.; Aguiar, A. C. M.; Kaspary, T. E.; Rigon, C. A. G. Winter cover crops on weed infestation and maize yield. Revista Caatinga, v.29, p.885-891, 2016. https://doi.org/10.1590/198321252016v29n413rc

Dass, A.; Shekhawat, K.; Choudhary, A. K.; Sepat, S.; Rathore, S. S.; Mahajan, G.; Chauhan, B. S. Weed management in rice using crop competition-a review. Crop Protection, v.95, p.45-52, 2017. https://doi.org/10.1016/j.cropro.2016.08.005

Ehlers, I.; Augusti, U. M.; Betson, T. R.; Nilsson, M. B.; Marshall, J. D.; Schleucher, J. Detecting long-term metabolic shifts using isotopomers: $\mathrm{CO}_{2}$-driven suppression of photorespiration in $\mathrm{C} 3$ plants over the $20^{\text {th }}$ century. Proceedings of the National Academy of Sciences, v.112, p.5585-15590, 2015. https://doi.org/10.1073/ pnas. 1504493112

Fang, Y.; Xiong, L. General mechanisms of drought response and their application in drought resistance improvement in plants. Cellular and Molecular Life Sciences, v.72, p.673-689, 2015. https://doi. org/10.1007/s00018-014-1767-0
Gantoli, G.; Ayala; V. R.; Gerhards, R. Determination of the critical period for weed control in corn. Weed Technology, v.27, p.63-71, 2013. https://doi.org/10.1614/WT-D-12-00059.1

Geissler, N.; Hussin, S.; El-Far, M. M. M.; Koyro, H. W. Elevated atmospheric $\mathrm{CO}_{2}$ concentration leads to different salt resistance mechanisms in a C3 (Chenopodium quinoa) and a C4 (Atriplex nummularia) halophyte. Environmental and Experimental Botany, v.118, p.67-77, 2015. https://doi.org/10.1016/j. envexpbot.2015.06.003

Lima, M. F. P.; Dombroski, J. L. D.; Freitas, F. C. L.; Pinto, J. R. S.; Silva, D. V. Weed growth and dry matter partition under water restriction. Planta Daninha, v.34, p.701-708, 2016. https://doi. org/10.1590/s0100-83582016340400010

Lisar, S. Y. S.; Motafakkerazad, R.; Hossain, M. M.; Rahman I. M. M. Water stress in plants: Causes, effects and responses. In: Rahman, I. M. M. (ed.) Water stress. Rijeka: INTECH, 2012. p.1-14.

Loon, L. C. van. The intelligent behavior of plants. Trends in Plant Science, v.21, p.286-294, 2016. https://doi.org/10.1016/j. tplants.2015.11.009

Luo, H. H.; Zhang, Y. L.; Zhang, W. F. Effects of water stress and rewatering on photosynthesis, root activity, and yield of cotton with drip irrigation under mulch. Photosynthetica, v.54, p.65-73, 2016. https://doi.org/10.1007/s11099-015-0165-7

Mickelbart, M. V.; Hasegawa, P. M.; Bailey-Serres, J. Genetic mechanisms of abiotic stress tolerance that translate to crop yield stability. Nature Reviews Genetics, v.16, p.237, 2015. https://doi. org/10.1038/nrg3901

Miner, G. L.; Bauerle, W. L.; Baldocchi, D. D. Estimating the sensitivity of stomatal conductance to photosynthesis: A review. Plant, Cell \& Environment, v.40, p.1214-1238, 2017. https://doi.org/10.1111/ pce. 12871

Moshelion, M.; Halperin, O.; Wallach, R.; Oren, R.; Way, D. A. Role of aquaporins in determining transpiration and photosynthesis in water-stressed plants: Crop water-use efficiency, growth and yield. Plant, Cell \& Environment, v.38, p.1785-1793, 2015. https:// doi.org/10.1111/pce.12410

Rodrigues, O. L.; Galvão, J. C. C.; Ferreira, E. A.; Silva, D. V.; Santos, M. V.; Ferreira, L. R.; Pereira, R. C.; Felipe, R. S. Physiologic characteristics of corn and Urochloa brizantha (Hochst. Ex A. Rich.) R.D. Webster in intercropping cultivation. Chilean Journal of Agricultural Research, v.74, p.74, 2014. http://dx.doi. org/10.4067/S0718-58392014000300002

Ryan, A. C.; Dodd, I. C.; Rothwell, S. A.; Jones, R.; Tardieu, F.; Draye, X. Davies, W. J. Gravimetric phenotyping of whole plant transpiration responses to atmospheric vapour pressure deficit identifies genotypic variation in water use efficiency. Plant Science, v.251, p.101-109, 2016. http://dx.doi.org/10.1016/j.plantsci.2016.05.018

Sharma, D. K.; Andersen, S. B.; Ottosen, C. O.; Rosenqvist, E. Wheat cultivars selected for high $\mathrm{Fv} / \mathrm{Fm}$ under heat stress maintain high photosynthesis, total chlorophyll, stomatal conductance, transpiration and dry matter. Physiologia Plantarum, v.153, p.284298, 2015. http://dx.doi.org/10.1111/ppl.12245

Sousa, R. S.; Bastos, E. A.; Cardoso, M. J.; Ribeiro, V. Q.; Brito, R. R. Desempenho produtivo de genótipos de milho sob déficit hídrico. Revista Brasileira de Milho e Sorgo, v.14, p.49-60, 2015. https:// doi.org/10.18512/1980-6477/rbms.v14n1p49-60

Tenhaken, R. Cell wall remodeling under abiotic stress. Frontiers in Plant Science, v.5, p.1-9, 2015. https://doi.org/10.3389/ fpls.2014.00771 
Uzildaya, I. B.; Turkan, I.; Sekmen, A. H.; Ozgur, R.; Karakaya, H. C. Comparison of ROS formation and antioxidant enzymes in Cleome gynandra (C4) and Cleome spinosa (C3) under drought stress. Plant Science, v.182, p.59-70. 2012. https://doi. org/10.1016/j.plantsci.2011.03.015
Yan, J.; Zhang, X. Y.; Chen, X.; Wang, Y.; Zhang, F.; Wan, F. H. Effects of rhizosphere soil microorganisms and soil nutrients on competitiveness of Bidens pilosa with different native plants. Biodiversity Science, v.24, p.1381-1389, 2016. https://doi. org/10.17520/biods.2015365 